\title{
Promoting Numeracy in an Online College Algebra Course through Projects and Discussions
}

Samuel L. Tunstall

Appalachian State University, stunstal@trinity.edu

Michael J. Bossé

Appalachian State University, bossemj@appstate.edu

Follow this and additional works at: https://digitalcommons.usf.edu/numeracy

Part of the Curriculum and Instruction Commons, Online and Distance Education Commons, and the Science and Mathematics Education Commons

\section{Recommended Citation}

Tunstall, Samuel L., and Michael J. Bossé. "Promoting Numeracy in an Online College Algebra Course through Projects and Discussions." Numeracy 8, Iss. 2 (2015): Article 10. DOI: http://dx.doi.org/10.5038/ 1936-4660.8.2.10 


\title{
Promoting Numeracy in an Online College Algebra Course through Projects and Discussions
}

\begin{abstract}
This research stems from efforts to infuse quantitative literacy (QL) in an online version of college algebra. College algebra fulfills a QL requirement at many universities, and it is a terminal course for most who take it. In light of the course's traditional content and teaching methods, students often leave with little gained in QL. An online platform provides a unique means of engaging students in quantitative discussions and research, yet little research exists on online courses in the context of QL. The course studied included weekly news discussions as well as "messy" projects requiring data analysis. Students in online and face-to-face sections of the course took the Quantitative Literacy and Reasoning Assessment ( QLRA; developed by members of the National Numeracy Network) during the first and final weeks of the fall 2014 semester. There were significant statistical gains in the online students' QLRA performance and mathematical affect but none for the face-to-face students. Notwithstanding limitations of the study, the results support the notion that project-based learning in an online environment is a promising strategy for promoting QL in terminal math courses.
\end{abstract}

\section{Keywords}

Quantitative literacy, college algebra, online learning, alternative assessment, problem-based learning

\section{Creative Commons License}

\section{c) (7) (8)}

This work is licensed under a Creative Commons Attribution-Noncommercial 4.0 License

\section{Cover Page Footnote}

Samuel Luke Tunstall, completing his Master's Degree in mathematics at Appalachian State University, Boone, NC, is a first-year doctoral student at Michigan State University in mathematics education. His research interests include the teaching of college algebra, online learning, quantitative literacy, and general education outcomes.

Michael. J. Bossé is the Distinguished Professor of Mathematics Education and MELT Program Director at Appalachian State University, Boone, NC. He teaches undergraduate and graduate courses and is active in providing professional development to teachers in North Carolina and around the nation. His research focuses on learning, cognition, and curriculum in K-16 mathematics. 


\section{Introduction}

Numbers matter. In this information age, they inundate our lives in ways beyond what many postsecondary college students would fathom. Conveying the harsh realities of our numbers-saturated world to students who have traditionally turned away from mathematics is a nontrivial and important challenge. Indeed, such students' numeracy, or ability to work with elementary mathematics in day-to-day life, is at stake and has an impact that permeates their lives in meaningful ways. Efforts to meet this challenge for students in first-year terminal math courses have been ongoing, though the continued existence of a reform movement indicates that this effort is as yet incomplete. In particular, instruction in college algebra courses appears most often to employ traditional lecture methods that may not promote quantitative literacy.

This paper ${ }^{1}$ presents an exploratory study on the efficacy of problem-based learning in an online environment to promote numeracy for college algebra students. The number of available online college courses continues to grow (Allen and Seaman 2014). Online courses can facilitate discussion among students, allow for student choice in assignments, and foster students' research and writing skills. These benefits align with those of a problem-based learning environment, thus motivating this study on the effect of both in tandem. To our knowledge, such an approach to foster numeracy has not been studied among college algebra students. Such research is necessary so that students in terminal college math courses develop the skills they need to navigate a life filled with numbers.

In particular, this study compares the growth in quantitative literacy (QL) among students in a traditional college algebra class to those in an online college algebra class that employs some additional project-based learning (PBL) while covering the same content in college algebra. Altogether, two variables (face-toface vs. online instruction, and conventional college algebra content vs. similar content with the addition of some PBL) are simultaneously investigated, and no attempt is made to disaggregate the findings among these variables. The online college algebra course with the addition of some PBL is considered in the whole. This study presents promising results and provides suggestions for future directions in research.

\section{Background and Framework for Quantitative Literacy}

Of the 1,791,046 bachelor's degrees conferred nationwide in 2012, 18,842 were in mathematics or statistics and 145,924 were in engineering or computer science

\footnotetext{
${ }^{1}$ This paper is derived from the Master's thesis of the first author under the supervision of the second author. References to "the researcher" indicate the first author.
} 
(Snyder and Dillow 2013). This means that roughly 8\% of students are preparing to tackle problems in engineering and computer science, about $1 \%$ are training to be mathematicians or statisticians, and $91 \%$ of students simply need mathematics to navigate their daily lives.

Accordingly, Colwell (2003) uses the word "numeracy" to describe the notion of using mathematics to navigate the daily demands of life. Many have also referred to numeracy as quantitative literacy $(\mathrm{QL})$ or quantitative reasoning (QR) (Burkhardt 2008). In this study, QL, QR, and numeracy are treated synonymously, through the definition of the charter of the MAA's SIGMAA on QL (2004):

Quantitative literacy (QL) can be described as the ability to adequately use elementary mathematical tools to interpret and manipulate quantitative data and ideas that arise in an individual's private, civic, and work life. Like reading and writing literacy, quantitative literacy is a habit of mind that is best formed by exposure in many contexts.

Additional elements in the researcher's framework for QL include communication and mathematical affect. While these are not explicit in the above definition, they are as important as mathematical ability. Wilkins (2010) developed a "multifaceted construct" for QL encompassing ability, self-efficacy, and one's beliefs about the utility of mathematics. Moreover, Hughes Hallet (2003), Wiggins (2003), and Lutsky (2008) argue for the importance of writing and argumentation in framing QL. Funneling these elements into one, this study views numeracy as that described in the charter along with the elements of communication and mathematical disposition. With a working definition in hand, we turn to the motivation for QL and for this study.

\section{Motivation for Numeracy}

While the underpinnings of the QL movement developed in the late twentieth century, its genesis is found in the seminal text Mathematics and Democracy (Steen 2001). From this text arose a proliferation of research and activity on college campuses. Indeed, soon after, the National Numeracy Network (NNN) formed with a mission of promoting QL at all levels (Madison and Steen 2008). Since 2004, the NNN has held annual meetings and now also publishes this journal, Numeracy, twice annually. In a similar vein as the NNN, in 2004 the Mathematics Association of America (MAA) formed a Special Interest Group on QL (SIGMAA-QL), which meets annually at the Joint Mathematics Meetings. The association released major publications in 2003, 2004, 2006, and 2008, all of which echo the call for increased attention to quantitative literacy at both the secondary and postsecondary levels. So in light of the meetings and work, one can easily ask: Why? For those interested in undergraduate mathematics education, key reasons include the link between QL ability and one's welfare, the tenuous status of first-year postsecondary math courses, and a growing movement for 
accountability in general education outcomes. These components are briefly addressed here.

To begin, researchers have found that mathematical ability is connected not only to wage increases and likelihood of fulltime employment (Rivera-Batiz 1992; Eide and Grogger 1995; Levy et al. 1995), but also forward thinking in one's personal finances (Lusardi 2012; Nye and Hillyard 2013). In addition, numeracy is linked with better decision-making (Peters et al. 2006; Jasper et al. 2013), nutrition label understanding (Rothman et al. 2006), as well as with better risk comprehension in healthcare (Fagerlin et al. 2007; Lipkus and Peters 2009).

In light of numeracy's potential impact on long-term well-being, it is understandable that educators would strive to develop it in students. However, many argue that the current sequence of math courses in secondary education geometry, algebra, trigonometry, and calculus (GATC) - is not conducive to effecting a numerate citizenry (Steen 2001). To Madison (2003, p. 154), the GATC sequence sifts "through millions of students to produce thousands of mathematicians, scientists, and engineers." That is, while intuition might suggest that courses in the GATC sequence develop QL in students, the reality is far different. The reason for this quandary is that mathematical and quantitative literacy are not equivalent (Steen 2001). Mathematical literacy provides a firm foundation for QL; however, it does not directly cause it, and it would be misleading to claim there is a simple relationship between the two (Madison 2003). As a simple example, one may be able to solve a quadratic equation but have no idea of how to interpret a percentage in a news article; such a student would exhibit mathematical literacy but not QL. Conversely, another individual may be able to interpret the percentage and discuss the author's argument, but not solve the quadratic equation. Indeed, numeracy and mathematical literacy are not the same.

The implications of this are important. Hughes Hallett (2003) suggests that although the foundations of QL are laid in middle-school, it is the responsibility of high-school and college faculty to cultivate this knowledge as students develop. As such, universities must carefully examine the courses they designate to fulfill general education requirements. If a student will not take a course past college algebra, and this college algebra course fulfills a general education requirement, the course must have some benefit aside from preparing a student for future math courses. A reason for calling attention to this responsibility is that college algebra - a course often taken by students who will not take calculus - has a particularly nasty reputation for its complicity in failing to foster QL. Madison (2003) and Steen (2004) lament the traditional college algebra course, noting that a great number of students never need to apply this content in later studies or in their careers. 
Seeking a fresh start, Small (2006) suggests that an improved college algebra course would have little lecture and instead a considerable number of small-group activities and projects; it should focus on real-world, ill-defined modeling rather than traditional word problems; it should contain a strong focus on communication and have little traditional assessment. And while Small's vision is admirable, college algebra at most U.S. universities does not fulfill his expectations. Data from a 2010 survey conducted by the American Mathematical Society (AMS) of four-year colleges and universities indicate that $29 \%$ of all nonremedial intro-level math enrollments are in college algebra, topping both precalculus and other liberal arts math courses for the introductory math course students take (Blair et al. 2010). College algebra also exceeds introductory statistics in course enrollments, as 242,000 students took the course in 2010, versus 231,000 taking an introductory statistics course. From a pedagogical standpoint, data from the survey reveal that only $16 \%$ of college algebra sections required writing assignments, and 65\% used a "traditional" lecture-based approach assessed through tests and quizzes, meaning the course content and delivery methods were essentially the same as those in 1990. Additionally, many of these college algebra courses are instructed by graduate students. With nearly a quarter-million students taking the course each year, these data are troubling.

Additionally, while college algebra is the focal course for this study, it is instructive to note that math for the liberal arts - designed as an alternative to precalculus or college algebra - has not been a panacea for all math departments. Though such courses formed to fulfill QL requirements, Ganter (2012) notes that most often these classes cover a broad survey of math topics or simply those that faculty desire to teach; they are rarely designed with the intent of developing students' quantitative reasoning ability. Richardson and McCallum (2003) use an apt analogy, suggesting that such courses teach one to appreciate a work of art (mathematics), rather than produce the art for oneself. Having said this, it is worthwhile to note that over the last five years a meaningful push has emerged towards legitimate QR-focused courses. Texts by Madison et al. (2012) and Crauder et al. (2014) exemplify this approach, with the former text discussed later in connection with this study. In summation, as the aforementioned AMS survey did not incorporate a category distinguishing math for the liberal arts from these more QL-focused courses, and no other data exist yet on their existence at fouryear colleges, it appears that Small's "fresh start" has not been realized.

\section{Fostering QL in a Problem-based, Online Learning Environment}

As college algebra remains so prominent in undergraduate math programs, it is essential to make every effort to fulfill its promise of being a course with QL designation. A novel yet promising approach for this task is to place college 
algebra online with a problem-based learning (PBL) structure. These dimensions are investigated below.

Problem-based learning is broadly characterized as an active learning approach where students develop content knowledge and other skills through selfdirected or group problem solving (Strobel and van Barnevald 2009). A traditional approach to teaching college mathematics - which would involve lecture followed by assessment through tests and quizzes - would not be considered PBL. In a meta-analysis of face-to-face PBL research, analysts found that it was superior compared to the traditional lecture approach in the areas of long-term content retention, skill development, and satisfaction of students and teachers (Strobel and van Barnevald 2009). Altogether, PBL aligns with the recommendations of numeracy experts. Indeed, according to Ganter (2012, p. 8), "Teaching methods for quantitative literacy courses are not lecture and listen, but they may involve group work, projects, writing, and many of the approaches advocated by those in the calculus reform movement." While PBL appears to be a promising approach to teaching QL-designated courses, caution is in order before simply implementing the strategy online. A careful delineation of online courses and their relation to $\mathrm{PBL}$ is in order first.

Online courses have been examined regarding their effectiveness when compared with face-to-face courses. Having examined more than 355 studies comparing distance courses (mostly online) to face-to-face counterparts, Russell (2001) released an initial hallmark analysis arguing that there was no significant difference between course-delivery mediums. A spate of other analyses followed. As no surprise, some meta-analyses have found that online learning is no different or superior (Bernard et al. 2004; Zhao et al. 2005; Caldwell 2006; Means et al. 2009), while others have found the opposite (Rovai 2002; Figlio et al. 2010; Tanyel and Griffin 2014). In particular, it has been found that online math courses - especially at the community college level - suffer from low retention rates (Mensch 2010; Xu and Jaggars 2011). Taking a step back, one sees that these studies do not contradict one another; rather, many measure success differently, ranging from student GPA and course retention to student performance on end-ofcourse exams and sense of classroom community. Nevertheless, it may seem disheartening that there is no definitive answer to the question of medium effectiveness; on the other hand, this may emphasize that quality instruction is what leads to student learning, regardless of course delivery mode (Oncu and Cakir 2011; Xu and Jaggars 2011). Consistent with face-to-face courses, some have suggested that best practices associated with online learning include that assessment should be diverse and allow for student choice (Robles and Braathen 2002; Gaytan and McEwen 2007; Gikandi et al. 2011;); moreover, it should depart from high-stakes tests and the promotion of surface learning (Reeves 2000; 
Rovai 2000; Speck 2002; Garrison 2003; Herron and Wright 2006; Vonderwell et al. 2007; Elliott 2008; Beebe et al. 2010).

Though the aforementioned researchers do not directly reference PBL, such quality instruction is in line with problem-based learning (Powers and Dallas 2006). In fact, studies have found significant increases in measures of students' critical-thinking skills upon taking an online PBL course (Cheaney and Ingebritsen 2006; Sendag and Odabasi 2009). Indeed, despite the fact that web students are not sitting in a classroom beside one another, a learning management system (LMS) permits collaboration (whether through discussion forums or wikis) as well as reflection time during communication (Wegerif 1998; Benson 2003; Meyer 2004; Chinnappan 2006; Larreamendy-Joerns and Leinhardt 2006; Perera-Diltz and Moe 2014;). In line with such communication, a meta-analysis suggests that discussion forums are powerful tools to increase student interaction and achievement (Blackmon 2012). From this, it can be seen that PBL can have a significant impact on QL in both online and face-to-face settings. As such, we now turn to examining how one determines if such a strategy is effective in promoting numeracy.

\section{Assessing Numeracy}

Over the last decade, researchers have performed a variety of small-scale studies to explore the nuances of teaching QL, many of which are found in Numeracy; however, at the time of this writing, no researcher has examined QL in an online environment. At the 2014 Joint Mathematics Meetings in Baltimore, the SIGMAA-QL focused on assessing numeracy, and a succession of institutions presented their techniques for assessment. Some universities, such as UMassBoston, Hood College, Colby-Sawyer College, and Central Washington University have designed assessments of their QL requirement (Boersma and Klyve 2014; Dunham 2014; Kilic-Bahi 2014; Mast 2014). The schools' evaluations typically account for some or all of the following elements: (1) communication skills, (2) mathematical disposition, and (3) ability to solve contextualized problems using elementary mathematics. While each institution's program assesses the second skill listed above, only those at Hood College and Central Washington University measured all three. Nonetheless, an issue in using any of these models for assessment is that all were designed with the respective college's specific QL goals in mind; none were designed for replication by others. Hence, not only may these be inappropriate for any particular university and set of students, but using one would not further the knowledge base of QL assessment measures. Given the time constraints within this study, we delimit our choice to one which would aid in accomplishing that goal. Indeed, as Scheaffer (2008, p. 12) noted in the opening issue of Numeracy, "QL research must strive for a strong base of systematic, coordinated and cumulative research from the outset." 
Fortunately to that end, Eric Gaze (NNN president) has worked with a crossinstitutional team of researchers over the past five years to design the Quantitative Literacy and Reasoning Assessment (QLRA); after years of edits for validity and reliability, the QLRA is now available online (Gaze et al. 2014). As of 2014, the QLRA includes 20 multiple-choice questions and five Likert-scale attitudinal questions. It can be used for pre- and post-tests of QL, and more than 25 institutions used it in 2013. It is designed to measure all three skills referenced above, although its assessment of communication is admittedly tenuous. The questions designed to assess communication require the student to simply choose a correct mathematical statement rather than produce their own. The QLRA's QLfocused mathematical content includes number sense (e.g., ratios in context, percent change, currency conversions), visual representation (e.g., common graphs found in a newspaper), reasoning (e.g., basic capture-recapture problems), and probability and statistics (e.g., interpretation of the median). Notwithstanding its weakness in assessing student writing, the QLRA is an ideal choice for the purposes of this study. It permits an investigation of the hypothesis discussed in the following section as well as a comparison of this institution's students' numeracy with that of students at other universities. As no research has specifically honed in on QL in an online environment, this study explores that gap and provides an avenue for future research.

\section{Methodology}

Study participants included a convenience sample of 57 students enrolled in two sections of college algebra at a midsized southeastern university in the U.S., where the primary responsibility for students meeting QL requirements resides in courses offered through the Mathematics Department. Twenty-eight of these students took the online section of the course, while the rest took the course in a traditional face-to-face lecture format. The demographics of the students in the two classes were very similar in a number of ways including: distributions of race and age; mathematical backgrounds; incoming mathematical abilities and attitudes; and the percentages of students who were taking the class as a terminal course vs. those who intended to take further mathematics.

The two sections used the same textbook and covered roughly the same sections in the text. The only sections covered in the face-to-face section but not in the online course were those on the conceptual notion of a derivative. Therefore, from the context of mathematical content, these two courses were very similar. The face-to-face course was traditional and lecture-based; tests comprised the majority of students' grades; and no specific additional focus was placed on QL - understanding that the course as designed was intended to meet university QL requirements. The online course necessarily placed somewhat less emphasis 
on a few mathematical topics in order to permit time for student discussions on real-world topics and readings. As a whole, students in the online course spent slightly more time on writing and discussing applications of the math content, and slightly less on computational homework problems. In light of the online section's non-traditional design, we give a more detailed description below.

The structure of the online course included traditional college algebra content quizzes, short Geogebra ${ }^{2}$ assignments, weekly discussion forums, and four major projects. There were no tests, and the discussions and data-driven projects comprised the majority of students' grades. Weekly forums included topics such as earthquakes in the news (the logarithmic Richter scale), Diana Nyad's controversial swim (the topic being concavity, in relation to a time vs. distance graph of her swim), and Thomas Malthus's essays on population growth. In addition, three of the news articles that students analyzed for the forums were taken from Case Studies for Quantitative Reasoning: A Casebook of Media Articles, by Madison et al. (2012), who spent several years crafting the text for a course in QR. Students analyzed these articles during weeks where their content was pertinent to the course. For the more substantial projects, topics included concavity in relation to population growth, GPA in relation to linear regression, viruses in relation to exponential growth, and the use of Gapminder ${ }^{3}$ to formulate and develop a model based on data. Clearly, all of the assignments were contextualized in some way and required students to communicate arguments or opinions using mathematics. As a whole, the course was designed so that - in addition to learning the content of college algebra - students would develop skills in mathematical communication, modeling, online research, and data analysis in Microsoft Excel. Altogether, the online course had two characteristics distinguishing it from the lecture-based section: the course was offered online rather than face-to-face, and the content instruction also included the experience of students performing four project-based learning activities and discussion forums.

The hypothesis in this study is that students in the online course with some PBL activities will have greater gains in QL. Both variables were intertwined within the intervention and no effort was made to disaggregate the findings based on one or the other variable. Having students complete PBL tasks in an online format allowed for both a rich opportunity for discussion and time for students to reflect upon their work and ideas and those of others. The purpose of the present study is to examine the efficacy of the online PBL environment in comparison to the traditional face-to-face approach. This study measured change in QL and not

\footnotetext{
${ }^{2}$ Geogebra is a free dynamic geometry software with capabilities for doing algebra, statistics, and calculus. One can learn more at https://www.geogebra.org/.

${ }^{3}$ Gapminder is a website with data on numerous economic and geographic indicators for each of the world's countries. One can access the site at http://www.gapminder.org/.
} 
ability in college algebra; there was no attempt to quantify differences in college algebra growth between the sections. However, with more time, this objective would have been an enlightening addition.

Staying in line with the study's framework for numeracy, students would be successful in QL growth if they improved their (1) communication skills, (2) mathematical disposition, and (3) ability to solve contextualized problems using elementary mathematics. Clearly such a variety of skills could be assessed in a simple exam - a mixed-methods approach was in order (Grawe, 2011). Here, this approach entailed having students in both courses take the QLRA and answer an open-ended survey question at the beginning and end of the semester. Also used were comments from the discussion forum as secondary data while recognizing that comparisons were unavailable as the forum was not an option for the face-toface course.

In analyzing the QLRA scores, the 20-question content portion of the QLRA and the Likert portion of the QLRA were treated separately. The Likert-scale questions were on a scale of 1-5, with 1 representing "Strongly Disagree" and 5 representing "Strongly Agree." For questions 1, 3, and 4, higher responses indicated that one had a positive disposition towards mathematics; for questions 2 and 5, lower scores indicated a positive disposition. In addition to taking the QLRA, all students answered a brief survey question when taking the exam: It has been said that "The world is awash with numbers." Do you use math in your daily life, or do you avoid doing calculations? The purpose of this question was to gain qualitative data about students' mathematical dispositions that the Likert-scale questions could not capture. The Likert-scale and survey items assessed skill 2 above, while the content questions addressed skill 3. As all the content questions required students to read carefully, and some even required students to pick the correct statement of mathematics, the assessment of skill 1 was somewhat assessed through these questions. However, it is conceded that communication was not fully captured through this approach. As a final source of evidence, comments from the online discussion forum throughout the semester were drawn upon. The comments chosen were those deemed notable because they presented some facet of QL from a student who did not necessarily perform well in the course as a whole. Because the online forum was clearly not a part of the face-toface course, comparisons cannot be made and will be used only as supplementary evidence.

As referenced above, a number of variables differentiated the two classes involved in this study. The face-to-face course was instructed and assessed through very traditional means. The online course introduced four additional project-based learning (PBL) activities, writing critiques of a small number of articles, and being assessed through alternative assessments rather than through traditional exams. Altogether, these numerous variables set the stage that they 
may all work together to confound the others. Disaggregating the data to speak to one variable at a time was not possible. Thus, this study cannot speak to any one dimension of the online, PBL, alternative assessment course; all components were considered simultaneously. The researcher posits that if the course were simply delivered online with exactly the same algebraic content covered in almost identical form as the face-to-face course, then one would not see differences in QL among the sections. Similarly, the researcher believes that if the course with the addition of some PBL activities were delivered in the face-to-face format, one would see mild gains in QL; however, they would not be as great as those potentially demonstrated by the online course with PBL activities.

\section{Results}

Figure 1 demonstrates that (on average) students in both sections improved their QLRA math content scores upon completing the course. As the students just completed a math course (perhaps not having taken one in years), it is reasonable that they would recall or gain basic math skills. While it can be seen that the online students began with a higher average than that of the face-to-face section, this difference was not found to be significant. In addition, it is instructive to note that neither course section made a large jump in the number of QLRA mathcontent questions answered correctly.

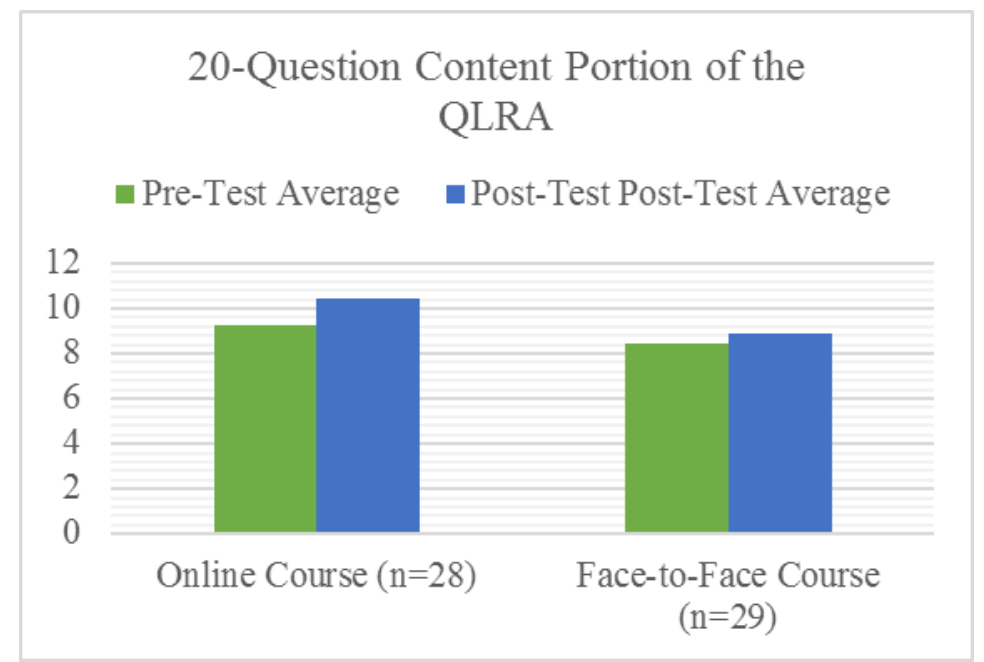

Figure 1. QLRA content-question results.

Figure 2 illustrates the changes in mathematical disposition over the course of the semester. Recall that a gain on questions 1,3 , and 4 is considered positive, with the opposite holding for questions 2 and 5. With this in mind, one can see positive gains for the online course in questions 1-4, but a loss on question 5 . As that question is not significantly different from the others, it is plausible that the 
loss is nothing of concern. Furthermore, we see mild gains in affect for the faceto-face section on questions $1,3,4$, and 5 ; however, there is a sizeable "loss" on question 2.

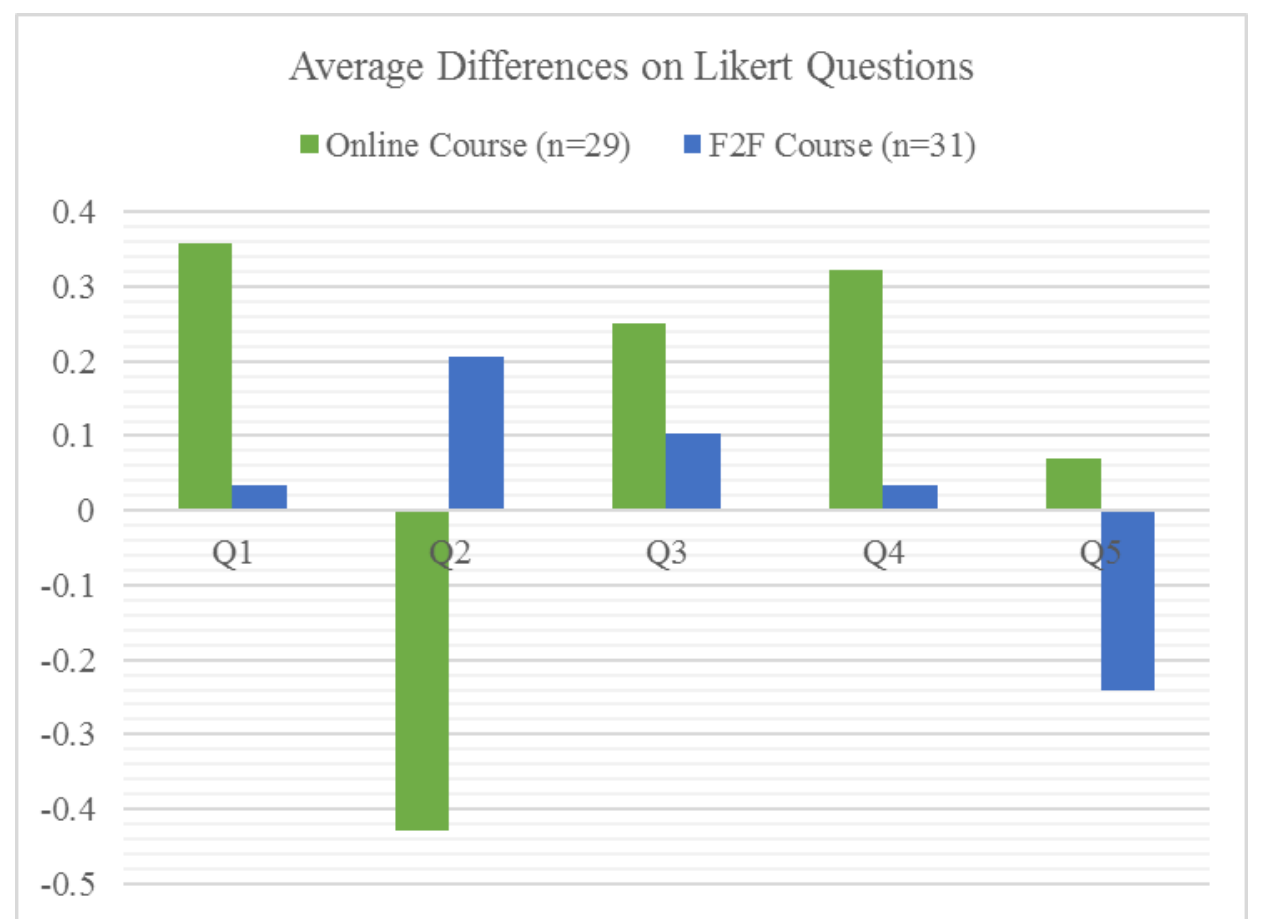

Figure 2. QLRA Likert-scale question results.

Table 1 shows that students in the online section made statistically significant gains in the QL math content while those in face-to-face section did not. It also illustrates the same pattern with respect to mathematical disposition through Likert-items 1, 2, and 4. Note the loss in Likert-item 5 for the online course is not significant, thus again confirming the notion that the result is of little concern.

Table 1.

Statistical analysis of QLRA results

\begin{tabular}{ccccc}
\hline & $\begin{array}{c}\text { Average Pre-Post } \\
\text { Online } \\
\text { Difference }\end{array}$ & $p$-value & $\begin{array}{c}\text { Average Pre-Post } \\
\text { Face-to-Face } \\
\text { Difference }\end{array}$ & $p$-value \\
\hline Math-Content Questions & 1.214 & $0.014^{*}$ & 0.414 & 0.186 \\
Likert Question 1 & 0.357 & $0.033^{*}$ & 0.034 & 0.439 \\
Likert Question 2 & -0.429 & $0.028^{*}$ & 0.103 & 0.793 \\
Likert Question 3 & 0.799 & 0.055 & 0.034 & 0.324 \\
Likert Question 4 & 0.393 & $0.043^{*}$ & -0.241 & 0.128 \\
Likert Question 5 & 0.071 & 0.635 & & 0.441 \\
\hline
\end{tabular}

Note: Asterisks indicate significant results at the $p<0.05$ level. 


\section{Discussion}

As shown in Table 1, although students in the online course demonstrated some small growth in their QL math-content scores, these changes were statistically significant. Simultaneously, gains in their disposition towards mathematics, as determined by the scores on the five Likert items, were statistically significant. However, students in the face-to-face section evidenced no significant gains on the QLRA content or improvement in mathematical disposition as a result of taking the course. The fact that the online students performed better on the QLRA math content is not necessarily surprising. Intuitively, one could simply posit that all students should perform better because they had seen the questions before and had just taken a math course; however, this notion would not explain why the face-to-face students did not perform significantly better. A more-plausible explanation is that nearly all of the QLRA questions require students to read carefully and communicate properly; the assessment components of the online course emphasized this. As no aspect of the online course taught to the exam and the content of the two courses were the same - it seems that, when an instructor includes proper mathematical vocabulary usage as part of assessment and grading, students improve their own ability to distinguish between correct and incorrect mathematical communication.

It is instructive to note that the QLRA math content is distinct from college algebra content. This study made no comparison regarding gains in course content knowledge; however, as college algebra content is not a component of QL, this is not a cause for concern. In addition, the researcher believes that if both sections were given a common college algebra final exam, the classes would perform similarly, save for a section on piecewise functions and one on derivatives, which the online class did not cover.

Admittedly, students' gains in respect to QLRA content were not as great as had been hoped by the research design. Nevertheless, these results indicate that students can gain content QL in an online PBL environment and that such gains can exceed those attained through traditional face-to-face delivery. Note that to some extent, this finding may be circular in nature - students improved in QLcontent knowledge when QL was a central emphasis of the course - nonetheless, it suggests that there is a positive future for numeracy in PBL online courses.

The statistically significant gains on the Likert-scale questions are also encouraging. Questions 1, 2, and 4 may be summarized as one's belief that quantitative information is useful in making decisions in day-to-day life. As discussed earlier, such a positive disposition towards numbers is a significant component of QL. In light of the fact that college algebra is a terminal course for many who take it, one's affect regarding math upon leaving the course has a potential to remain with them. In contrast to the math content, the researcher did 
make specific efforts to better students' numerical attitudes throughout the semester. Many of the discussion forums and projects had a real-world focus and permitted students to investigate mathematical topics they found interesting. The payoff from this effort is then natural: students began to see math in a morepositive light. It is believed that this desired outcome would not have occurred without such alternative assessments. Students in the face-to-face section completed homework and prepared for quizzes and exams; aside from "word problems" in the text, they did not have the opportunity to find for themselves the applications of what they were learning.

Indeed, a significant difference between the online PBL course and the traditional face-to-face course was in the amount of mathematically based reading and writing experienced in the courses, with the online course requiring considerably more. Numerous researchers argue that reading is a unique mode of learning essential for mathematics understanding (e.g., Bishop 1988; Siegel and Borasi 1992; Borasi et al. 1998). Writing in mathematics similarly deepens mathematical understanding and extends thinking by sustaining students' development of reasoning, communication and connections (e.g., Shepard 1993; Grossman et al. 1993; Drake and Amspaugh 1994; Doherty 1996; Porter and Massingila 2000). Marks and Mousley (1990) contend that meaningful reading and writing experiences are rare in traditional face-to-face mathematics courses. Since students demonstrate a more-positive disposition when they understand concepts and are effectively learning, and they learn more effectively through reading and writing, it is reasonable that the online PBL-based course structure would produce marked gains in QL disposition.

As mentioned earlier, students also responded to an open-ended question when taking the QLRA. The results of this bolster the disposition findings above. In the replies from the face-to-face section, most students noted that calculations were important in day-to-day life but that they never found themselves needing "advanced" math; students answered similarly in the post-test. Among the online students, most initially gave a response akin to that of the face-to-face students; however, their post-test responses were distinct and quite detailed. Many of the students referenced specific course assignments - or topics they learned about in their research - as reasons that the world was filled with numbers. A typical response from each section to question (1) is given in Table 2.

It could be argued that students in the online course provided more-expansive responses to open-ended prompts because of the continual discussion they participated in as part of the QL-promoting investigations. While this may be the case in part, nevertheless, the responses by these students were quantitatively (length) and qualitatively (substance) different from those of the students in the face-to-face course, even in the cases of students who passed the course with 
lower grades. Thus, again, the online environment demonstrates potential to promote positive dispositions in QL.

Table 2.

Typical responses to an open-ended question.

\begin{tabular}{|c|c|c|}
\hline & $\begin{array}{c}\text { Pre-Test Response (From the same } \\
\text { individual) }\end{array}$ & $\begin{array}{l}\text { Post-Test Response (From the same } \\
\text { individual) }\end{array}$ \\
\hline Face-to-Face Course & $\begin{array}{l}\text { I use them usually with a calculator, } \\
\text { but I don't use any sort of formula in } \\
\text { everyday life. I probably would not } \\
\text { as day to day calculations don't } \\
\text { usually require more than a } \\
\text { calculator. }\end{array}$ & $\begin{array}{l}\text { I do use them in my everyday life. } \\
\text { There are a lot of things that require } \\
\text { numbers and to live without making } \\
\text { calculations would be very difficult. }\end{array}$ \\
\hline Online Course & $\begin{array}{l}\text { I do use math often, probably every } \\
\text { day. I probably use it more than I } \\
\text { realize. }\end{array}$ & $\begin{array}{l}\text { Surely, math is used in everyday life. } \\
\text { Whether it is seeing how much } \\
\text { longer we can sleep in before } \\
\text { missing our bus, to calculating tips, } \\
\text { to crunching numbers on } \\
\text { performance evaluations, math } \\
\text { cannot (and probably should not) be } \\
\text { avoided. I think math can certainly } \\
\text { be used more if used correctly. For } \\
\text { starters, it is much easier to judge } \\
\text { news articles as reliable when graphs } \\
\text { and stats are understood. It is more } \\
\text { understandable if a virus is really } \\
\text { growing exponentially or if that } \\
\text { word is just used incorrectly. }\end{array}$ \\
\hline
\end{tabular}

A final source of promising evidence for the online approach is comments drawn from the online course's discussion forums. Students responded positively to forums on concavity, exponential and logistic growth, and logarithmic functions (among others). A key in designing these forums was relating the topic to news events, famous figures, or ideas students could explore. With concavity, students discussed a time vs. distance graph of Diana Nyad's swim from Cuba to Florida; for exponential and logistic growth they researched the ideas of Thomas Malthus and Pierre Verhulst; for the Richter scale they examined recent earthquakes and how the damage described in media articles corresponded to the math of logarithms. Such discussions were not difficult to design but do require legitimate effort on the instructor's part; they promote numeracy because students who see math in the real-world are more apt to view the discipline in a positive light. Sample comments from the forums are included in Table 3. Information about the students' course performance is included to support the notion that it is not simply the high-achieving students who make numerate comments in the forums. Again, these results may speak to the results of learning mathematics through reading and writing, as they were more emphasized in the online course. 
Table 3.

Example forum comments from the online course

\begin{tabular}{|c|c|c|c|}
\hline Student & Forum Topic & Comment & $\begin{array}{l}\text { Course } \\
\text { Grade }\end{array}$ \\
\hline 1 & $\begin{array}{l}\text { The mathematics of } \\
\text { the Ebola outbreak }\end{array}$ & $\begin{array}{l}\text { This article isn't good. It makes the claim that Ebola is growing } \\
\text { exponentially but never uses math or any proof that it is growing } \\
\text { that way. They use WHO as a source but all they claim is that } \\
\text { WHO said it was growing exponentially. They need more proof to } \\
\text { back up their claims and valuable sources. }\end{array}$ & B \\
\hline 2 & $\begin{array}{l}\text { Logarithms and } \\
\text { earthquakes }\end{array}$ & $\begin{array}{l}\text { Now that I understand how the Richter scale compares the } \\
\text { different earthquakes, it puts it in perspective how powerful these } \\
\text { earthquakes are that devastate the West Coast and the rest of the } \\
\text { world. To see that an earthquake in Chile can be } 158.5 \text { times more } \\
\text { powerful then the one in San Francisco is astonishing to see even } \\
\text { when the one in San Francisco was still so devastating to the area. }\end{array}$ & $\mathrm{D}$ \\
\hline 3 & $\begin{array}{l}\text { Concavity and Diana } \\
\text { Nyad's swim }\end{array}$ & $\begin{array}{l}\text { The graph is increasing and has the general starting shape of a } \\
\text { concave down graph. The average rate of change from one mile } \\
\text { marker to the other is not consistent. I can image that swimming } \\
110 \text { miles from Cuba to Florida is not an easy task and her body } \\
\text { could not physically swim at a constant rate the whole time. My } \\
\text { guess is that she had some extra help along the way. It is just hard } \\
\text { for me to wrap around the concept that she was only able to swim } \\
\text { about } 4 \text { miles in } 255 \text { minutes but a miraculous } 17.21 \text { miles in } 239 \\
\text { minutes. Regardless, I give Nyad credit for even attempting to do } \\
\text { this at the age of } 64 \text { ! The graph clearly shows that she traveled the } \\
\text { whole distance, but I highly doubt that she did it all by herself. }\end{array}$ & B \\
\hline
\end{tabular}

\section{Conclusion}

The results of this study support the notion that, if the goal is to improve QL in a college algebra course, providing the course through $\mathrm{PBL}$ in an online environment can produce positive results. In this study, surprisingly little PBL experiences (only four projects and a small number of discussion forums) were employed in the online course; and yet significant results were seen in student growth in QL - particularly in comparison to the traditional face-to-face group. This finding has some important implications. First, very little change is needed to the structure and materials in a college algebra course in order to facilitate student growth in QL. The same algebraic content can be covered with only small additions of PBL, and QL growth can emerge. Since the online course in this study did not attempt to make sweeping alterations to the traditional college algebra course, one must wonder how much greater QL growth could be generated with even slightly more PBL experiences.

Second, there is no need to fear online learning environments, when they are properly developed and executed. Indeed, PBL and online instruction can work in tandem to produce both mathematical learning and QL growth in college algebra students. This bodes well for the future of college mathematics as it seeks to meet the QL needs of students. 


\section{Limitations and Further Directions}

The central goal of this exploratory study was to examine the efficacy of an online, PBL environment in promoting QL in a college algebra course. The results of the study confirm the researcher's hypothesis and provide strong preliminary evidence that such an approach can be effective. Notwithstanding, due to the logistics of the study, there are limitations to the findings. To begin, the study does not show causation; issues include the lack of subject randomization as well as differing course instructors. Moreover, the study does not account for whether the online environment, alternative assessment, or a mixture of the two is responsible for gains in students' QL. Future studies should compare all of these variations in order to isolate key factors. Such an environment is likely to remain prominent in both students' lives and as a course-delivery medium for the foreseeable future. As such, mathematics instructors must understand the online, PBL environment's ability to foster numeracy. For in a world "awash with numbers," we are the lifeguards keeping students afloat.

\section{References}

Allen, I. E., and J. Seaman. 2014. Grade change: tracking online education in the United States. http://www.onlinelearningsurvey.com/reports/gradechange.pdf (accessed December 9, 2014).

Beebe, R., S. Vonderwell, and M. Boboc. 2010. Emerging patterns in transferring assessment practices from F2f to online environments. Electronic Journal of E-Learning 8 (1): 1-12. http://files.eric.ed.gov/fulltext/EJ880094.pdf (accessed December 11, 2014).

Benson, A. D. 2003. Assessing participant learning in online environments. New Directions for Adult \& Continuing Education 2003 (100): 69-78. http://dx.doi.org/10.1002/ace.120 (accessed December 11, 2014).

Bernard, R. M., P. Abrami, Y. Lou, E. Borokhovski, A. Wade, L. Wozney, P. A. Wallet, M. Fiset, B. Huang. 2004. How does distance education compare with classroom instruction? A meta-analysis of the empirical literature. Review of Educational Research 74 (3): 379-439. http://dx.doi.org/10.3102/00346543074003379

Bishop, A. 1988. Mathematical enculturation. Dordrecht, The Netherlands: Kluwer Academic. http://dx.doi.org/10.1007/978-94-009-2657-8

Blackmon, S. J. 2012. Outcomes of chat and discussion board use in online learning: A research synthesis. Journal of Educators Online 9 (2): 1-19. 
Blair, R., E. Kirkman, and J. Maxwell. 2010. Statistical abstract of undergraduate programs in the mathematical sciences in the United States: Fall 2010 CBMS survey. American Mathematical Society. http://www.ams.org/cbms/cbms2010-Report.pdf (accessed December 9, 2014).

Boersma, S., and D. Kylve. 2014. Measuring habits of mind: Toward a promptless instrument for assessing quantitative literacy. Presented at the Joint Math Meetings. Baltimore, MD. http://sigmaa.maa.org/ql/_meetings/jmm2014/1096-B1-1643-slides.pdf (accessed December 9, 2014).

Borasi, R., M. Siegel, J. Fonzi, and C. F. Smith. 1998. Using transactional reading strategies to support sense-making and discussion in mathematics classrooms: An exploratory study. Journal for Research in Mathematics Education 29 (3): 275-305. http://dx.doi.org/10.2307/749791

Burkhardt, H. 2008. Quantitative literacy for all: How can we make it happen? In Calculation vs. context: Quantitative literacy and its implications for teacher education, eds. B. L. Madison and L. A. Steen, 137-162. Washington, DC: Mathematical Association of America. http://www.maa.org/external_archive/QL/cvc/CalcVsContext.pdf (accessed August 10, 2014).

Caldwell, E. R. 2006. A comparative study of three instructional modalities in a computer programming course: Traditional instruction, web-based instruction, and online instruction. Ph.D. diss, University of North Carolina at Greensboro. Ann Arbor: ProQuest/UMI. (Publication No. AAT 3227694.).

Cheaney, J., and T. Ingebritsen. 2006. Problem-based learning in an online course: A case study. The International Review of Research in Open and Distance Learning 6 (3). http://www.irrodl.org/index.php/irrodl/article/view/267/433 (accessed December 10, 2014).

Chinnappan, M. 2006. Using the productive pedagogies framework to build a community of learners online in mathematics education. Distance Education 27 (3): 355-369. http://dx.doi.org/10.1080/01587910600940430 (accessed December 9, 2014).

Colwell, R. 2003. Quantitative literacy goals: Are we making progress? In Madison and Steen 2003, 243-246.

Crauder, B., Evans, B., Johnson, J., and A. Noell. 2014. Quantitative literacy: Thinking between the lines, 2nd ed. W. H. Freeman. 
Doherty, B. J. 1996. The write way: A look at journal writing in first-year algebra. Mathematics Teacher 89 (7): 556-560.

Drake, B. M., and L. B. Amspaugh. 1994. What writing reveals in mathematics. Focus on Learning Problems in Mathematics 16 (3): 43-50.

Dunham, J. B. 2014. Standardizing assessment across QL courses. Presented at the Joint Math Meetings. Baltimore, MD. http://sigmaa.maa.org/ql/_meetings/jmm2014/1096-B1-2626-slides.pdf (accessed June 28, 2014).

Eide, E., and J. Grogger. 1995. Changes in college skills and the rise in the college wage premium. Journal of Human Resources 30 (2): 280-310. http://dx.doi.org/10.2307/146120

Elliott, R. J. 2008. Assessment 2.0. International Journal of Emerging Technologies in Learning 3 (S1): 66-70. http://wiki.cetis.ac.uk/images/d/de/Assessment_2_v2.pdf (accessed December 11, 2014).

Fagerlin, A., P. Ubel, D. Smith, and B. Zikmund-Fisher. 2007. Making numbers matter: Present and future research in risk communication. American Journal of Health Behavior 31: S47-56. http://dx.doi.org/10.5993/AJHB.31.s1.7

Figlio, D. N., M. Rush, and L. Yin. 2010. Is it live or is it internet? Experimental estimates of the effects of online instruction on student learning. Cambridge, Mass: National Bureau of Economic Research. http://dx.doi.org/10.3386/w16089 (accessed December 11, 2014).

Ganter, S. L. 2012. Issues, policies, and activities in the movement for quantitative literacy. In Current practices in quantitative literacy, ed. R. Gillman, 11-16. Washington, DC: Mathematical Association of America.

Garrison, D. R. 2003. Cognitive presence for effective asynchronous online learning: The role of reflective inquiry, self-direction and metacognition. In Elements of quality online education: practice and direction, ed. J. Bourne, and J. Moore, 47-58. Needham, MA: Sloan Consortium.

Gaytan, J., and B. C. McEwen. 2007. Effective online instructional and assessment strategies. The American Journal of Distance Education 21 (3): 117-132. http://dx.doi.org/10.1080/08923640701341653 (accessed December 9, 2014).

Gaze, E. C., A. Montgomery, S. Kilic-Bahi, D. Leoni, L. Misener, and C. Taylor. 2014. Towards developing a quantitative literacy/reasoning assessment instrument. Numeracy 7 (2): Article 4. http://dx.doi.org/10.5038/19364660.7.2.4 (accessed October 10, 2014). 
Gikandi, J. W., D. D. Morrow, and N. E. Davis. 2011. Online formative assessment in higher education: A review of the literature. Computers \& Education 57 (4): 2333-2351. http://dx.doi.org/10.1016/j.compedu.2011.06.004 (accessed December 11, 2014).

Grawe, N. D. 2011. Beyond math skills: Measuring quantitative reasoning in context. New Directions for Institutional Research 2011 (149): 41-52. http://dx.doi.org/10.1002/ir.379 (accessed December 10, 2014).

Grossman, F. J., B. Smith, and C. Miller. 1993. Did you say "write” in mathematics class? Journal of Developmental Education 22 (4): 2-6.Herron, J. F., and V. H. Wright. 2006. Assessment in online learning: Are students really learning? In Research on enhancing the interactivity of online learning, ed. V. H. Wright, C. S. Sunal, and E. K. Wilson, 45-64. Information Age Publishing.

Hughes Hallett, D. 2003. The role of mathematics courses in the development of quantitative literacy. In Madison and Steen 2003, 91-98.

Jasper, J. D., C. Bhattacharya, I. P. Levin, L. Jones, and E. Bossard. 2013. Numeracy as a predictor of adaptive risky decision making. Journal of Behavioral Decision Making 26 (2): 164-173. http://dx.doi.org/10.1002/bdm.1748 (accessed December 10, 2014).

Kilic-Bahi, S. 2014. QL across the curriculum at Colby-Sawyer College. Presented at the Joint Math Meetings. Baltimore, MD. http://sigmaa.maa.org/ql/_meetings/jmm2014/1096-B1-2118-slides.pdf (accessed August 29, 2014).

Larreamendy-Joerns, J., and G. Leinhardt. 2006. Going the distance with online education. Review of Educational Research 76 (4): 567-605. http://dx.doi.org/10.3102/00346543076004567 (accessed December 11, 2014).

Levy, F., R. J. Murnane, and J. B. Willett. 1995. The growing importance of cognitive skills in wage determination. Review of Economics and Statistics 77 (2): 251-266. http://dx.doi.org/10.2307/2109863 (accessed December 10, 2014).

Lipkus, I. M., and E. Peters. 2009. Understanding the role of numeracy in health: Proposed theoretical framework and practical insights. Health Education \& Behavior 36 (6): 1065-1081. http://dx.doi.org/10.1177/1090198109341533 (accessed July 9, 2014).

Lusardi, A. 2012. Numeracy, financial literacy, and financial decision-making. Numeracy 5 (1): Article 2. http://dx.doi.org/10.5038/1936-4660.5.1.2 (accessed March 12, 2015) 
Lutsky, N. 2008. Arguing with numbers: Teaching quantitative reasoning through argument and writing. In Madison and Steen 2008, 59-74.

Madison, B. L. 2003. Articulation and quantitative literacy: A view from inside mathematics. In Madison and Steen 2003, 153-164.

- and L. A. Steen, eds. 2003. Quantitative literacy: Why numeracy matters for schools and colleges. Princeton, NJ: National Council on Education and the Disciplines. http://www.maa.org/sites/default/files/pdf/QL/WhyNumeracyMatters.pdf (accessed December 9, 2014).

- 2008. Evolution of Numeracy and the National Numeracy Network. Numeracy 1 (1): Article 2. http://dx.doi.org/10.5038/1936-4660.1.1.2 (accessed December 10, 2014).

- 2008. Calculation vs. context: Quantitative literacy and its implications for teacher education. Mathematical Association of America. https://www.maa.org/external_archive/QL/cvc/CalcVsContext.pdf (accessed December 10, 2014).

Madison, B. L., S. Boersma, C. L. Diefenderfer, and S. W. Dingman. 2012. Case Studies for Quantitative Reasoning: A Casebook of Media Articles. Pearson Learning Solutions.

Marks, G., and J. Mousley. 1990. Mathematics, education and genre: Dare we make the process writing mistake again? Language and Education 4 (2): 117135. http://dx.doi.org/10.1080/09500789009541278

Mast, M. B. 2014. Three approaches to assessment in the quantitative reasoning classroom. Presented at the Joint Math Meetings. Baltimore, MD. http://sigmaa.maa.org/ql/_meetings/jmm2014/1096-B1-2424-slides.pdf (accessed December 10, 2014).

Means, B., Y. Toyama, R. Murphy, M. Bakia, K. Jones, Office of Planning, Evaluation and Policy Development Department of Education (ED), and International SRI. 2009. Evaluation of evidence-based practices in online learning: A meta-analysis and review of online learning Studies. US Department Of Education.

Mensch, S. 2010. Issues in offering numeric based courses in an online environment. Journal of Instructional Pedagogies 3. http://www.aabri.com/manuscripts/09405.pdf (accessed December 8, 2014).

Meyer, K. A. 2004. Evaluating online discussions: Four different frames of analysis. Journal of Asynchronous Learning Networks 8 (2): 101-114. http://olc.onlinelearningconsortium.org/sites/default/files/v8n2_meyer_1.pdf (accessed December 9, 2014). 
Nye, P., and C. Hillyard. 2013. Personal financial behavior: The influence of quantitative literacy and material values. Numeracy 6 (1): Article 3. http://dx.doi.org/10.5038/1936-4660.6.1.3 (accessed March 12, 2015)

Oncu, S., and H. Cakir. 2011. Research in online learning environments: Priorities and methodologies. Computers \& Education 57 (1): 1098-1108. http://dx.doi.org/10.1016/j.compedu.2010.12.009 (accessed December 11, 2014).

Perera-Diltz, D., and J. Moe. 2014. Formative and summative assessment in online education. Journal of Research in Innovative Teaching 7 (1): 130-142. http://www.nu.edu/assets/resources/pageResources/journal-of-research-ininnovative-teaching-volume-7.pdf (accessed December 11, 2014).

Peters, E., D. Västfjäll, P. Slovic, C. K. Mertz, K. Mazzocco, and S. Dickert. 2006. Numeracy and decision making. Psychological Science 17 (5): 407413. http://dx.doi.org/10.1111/j.1467-9280.2006.01720.x

Porter, M. K., and J. O. Masingila. 2000. Examining the effects of writing on conceptual and procedural knowledge in calculus. Educational Studies in Mathematics 42 (2): 165-177. http://dx.doi.org/10.1023/A:1004166811047

Powers, S., and L. Dallas. 2006. Authentic assessment through problem-based learning in the online environment. In Research on enhancing the interactivity of online learning, ed. V. H. Wright, C. S. Sunal, and E. K. Wilson, 65-78. Information Age Publishing.

Reeves, T. C. 2000. Alternative assessment approaches for online learning environments in higher education. Journal of Educational Computing Research 23(1): 101-111.

Richardson, R. M., and W. G. McCallum. 2003. The third R in literacy. In Madison and Steen 2003, 99-106. http://www.maa.org/external_archive/QL/pgs99_106.pdf (accessed December 9, 2014).

Rivera-Batiz, F. L. 1992. Quantitative literacy and the likelihood of employment among young adults in the United States. Journal of Human Resources 27 (2): 313-328. http://dx.doi.org/10.2307/145737 (accessed December 9, 2014).

Robles, M., and S. Braathen. 2002. Online assessment techniques. Delta Pi Epsilon Journal 44 (1): 39-49.

Rothman, R. L., R. Housam, H. Weiss, D. Davis, R. Gregory, T. Gebretsadik, A. Shintani, and T. A. Elasy. 2006. Patient understanding of food labels: The role of literacy and numeracy. American Journal of Preventive Medicines 31 (5): 391-398. http://dx.doi.org/10.1016/j.amepre.2006.07.025 (accessed December 9, 2014). 
Rovai, A. P. 2000. Online and traditional assessments: What is the difference? Internet and Higher Education 3 (3): 141-51. http://dx.doi.org/10.1016/S1096-7516(01)00028-8

.2002. A preliminary look at structural differences in sense of classroom community between higher education traditional and ALN courses. Journal of Asynchronous Learning Networks 6 (1): 41-56. http://olc.onlinelearningconsortium.org/sites/default/files/v6n1_rovai_1.pdf (accessed December 11, 2014).

Russell, T. L. 2001. The no significant difference phenomenon: A comparative research annotated bibliography on technology for distance education. Montgomery, AL: IDECC.

Scheaffer, R. L. 2008. Scientifically based research in quantitative literacy: Guidelines for building a knowledge base. Numeracy 1 (1): Article 3. http://dx.doi.org/10.5038/1936-4660.1.1.3 (accessed June 6, 2014).

Sendag, S., and H. F. Odabasi. 2009. Effects of an online problem based learning course on content knowledge acquisition and critical thinking skills. Computers \& Education 53 (1): 132-141. http://dx.doi.org/10.1016/j.compedu.2009.01.008 (accessed July 14, 2014).

Shepard, R. G. 1993. Writing for conceptual development in mathematics. Journal of Mathematical Behavior 12 (3): 287-293.

Siegel, M., and R. Borasi. 1992. Toward a new integration of reading in mathematics instruction. FOCUS on Learning Problems in Mathematics 14 (2): 18-36.

SIGMAA in Quantitative Literacy. 2004. Charter for SIGMAA on QL. http://sigmaa.maa.org/ql/_charters/2004.php (accessed July 14, 2014).

Small, D. 2006. College algebra: A course in crisis. In A fresh start for collegiate mathematics: Rethinking the courses below calculus, eds. N. Hastings, F. Gordon, S. Gordon, and J. Narayan, 83-89. Washington, DC.

Snyder, T. D., and S. A. Dillow. 2013. Digest of education statistics, 2012. http://nces.ed.gov/pubsearch/pubsinfo.asp?pubid=2014015 (accessed November 2, 2014).

Speck, B. W. 2002. Learning-teaching-assessment paradigms and the on-line classroom. New Directions for Teaching \& Learning 2002 (91): 5-18. http://dx.doi.org/10.1002/tl.61 (accessed December 11, 2014).

Steen, L. A. (exec. ed). 2001. Mathematics and democracy: The case for quantitative literacy. The Woodrow Wilson National Fellowship Foundation, National Council on Education and the Disciplines. http://www.maa.org/ql/mathanddemocracy.html (accessed October 8, 2014). 
. 2004. Achieving quantitative literacy: An urgent challenge for higher education. [Washington, D.C.]: Mathematical Association of America.

Strobel, J., and Angela van Barneveld. 2009. When is PBL more effective? A meta-synthesis of meta-analyses comparing PBL to conventional classrooms. Interdisciplinary Journal of Problem-Based Learning 3 (1): 44-58. http://dx.doi.org/10.7771/1541-5015.1046

Tanyel, F., and J. Griffin. 2014. A ten-year comparison of outcomes and persistence rates in online versus face-to-face courses. B>Quest 1-22. http://www.westga.edu/ bquest/2014/onlinecourses2014.pdf (accessed December 9, 2014).

Vonderwell, X. Liang, X., and K. Alderman. 2007. Asynchronous discussions and assessment in online learning. Journal of Research on Technology in Education 30 (3): 309-328. http://dx.doi.org/10.1080/15391523.2007.10782485

Wegerif, R. 1998. The social dimension of asynchronous learning networks. Journal of Asynchronous Learning Networks 2 (1): 34-49. http://greguns2.gre.ac.uk/ET/ELD/KNTI/etutres.NSF/76cf225430685dbc8025651a007 59c95/488fccf932adb510802570000031ae79/\$FILE/v2n1_wegerif.pdf (accessed December 11, 2014).

Wiggins, G. 2003. “Get Real!” Assessing for Quantitative Literacy. In Madison and Steen 2003, 121-43.Wilkins, J. 2010. Modeling quantitative literacy. Educational and Psychological Measurement 70 (2): 267-290. http://dx.doi.org/10.1177/0013164409344506 (accessed September 19, 2014)

$\mathrm{Xu}, \mathrm{D}$., and S. S. Jaggars. 2011. The effectiveness of distance education across Virginia's community colleges: Evidence from introductory college-level math and English courses. Educational Evaluation and Policy Analysis 33 (3): 360-377. http://dx.doi.org/10.3102/0162373711413814 (accessed October 11, 2014).

Zhao, Y., J. Lei, B. Yan, C. Lai, and H. Tan. 2005. What makes the difference? A practical analysis of research on the effectiveness of distance education. Teachers College Record 107 (8): 1836-1884. 